\title{
Use of solar radiation in the improvement of spring canola (Brassica napus L., Brassicaceae) yield influenced by nitrogen topdressing fertilization
}

\author{
Genei Antonio Dalmago ${ }^{1\left(^{*}\right)}$, Daniele Gutterres Pinto ${ }^{2}$, Denise Cybis Fontana ${ }^{2}$, Jorge Alberto de Gouvêa ${ }^{1}$, Homero Bergamaschi $^{2}$, \\ Elizandro Fochesatto ${ }^{3}$ and Anderson Santi ${ }^{1}$ \\ 'Embrapa Trigo, Rodovia BR 285, km 294, Caixa Postal 3081, CEP 99050-970 Passo Fundo, RS, Brazil. E-mail: genei.dalmago@embrapa.br, \\ jorge.gouvea@embrapa.br and anderson.santi@embrapa.br \\ ${ }^{2}$ Universidade Federal do Rio Grande do Sul - Faculdade de Agronomia. Avenida Bento Gonçalves, 7712, Caixa Postal 15096, CEP 91501.970. Porto Alegre, \\ RS, Brazil. E-mails: daniele.gutterres@gmail.com, dfontana@ufrgs.br and homerobe@ufrgs.br \\ ${ }^{3}$ Faculdades Integradas do Vale do Iguaçu-Uniguaçu. Rua Padre Saporiti, 717, Bairro Rio D’Areia, CEP 84600-904 União da Vitória, PR, Brazil. \\ E-mail: elizandrofochesato@hotmail.com \\ ${ }^{(*)}$ Corresponding author.
}

\section{ARTICLE INFO}

Article history:

Received 15 June 2018

Accepted 20 December 2018

Index terms:

Brassica napus

dry matter

leaf area index

photosynthetically active radiation

light extinction coefficient
ABSTRACT

The objective of the present study was to quantify and evaluate the coefficients of interception, absorption, and use of photosynthetically active solar radiation (PAR), and its effects on grain yield (YLD) of spring canola influenced by $\mathrm{N}$ topdressing fertilization. Two experiments were performed in 2013 and 2014 using a randomized block design, with four replicates and five treatments of N: T1-T5 (10, 20, 40, 80, and $160 \mathrm{~kg} \mathrm{ha}^{-1}$, respectively). Plant, PAR, and meteorological variables were measured. The lower PAR interception efficiency $\left(\varepsilon_{i}\right)$ occurred in treatment T1. The range of light extinction coefficient $(\mathrm{k})$ was of the 0.55 to 1.09 . PAR absorption efficiency $\left(\varepsilon_{a}\right)$ ranged from 86 to $93 \%$, while the PAR use efficiency (RUE) ranging from 1.2 to to $3.7 \mathrm{~g} \mathrm{~m}^{-2} \mathrm{MJ}^{-1}$. The mean $\mathrm{N}$ dose for maximum agronomic efficiency (MAE) for YLD was $99.3 \mathrm{~kg} \mathrm{ha}^{-1}$. The YLD varied according to $\mathrm{N}$ treatments and was influenced by RUE, dry matter accumulated until flowering (DMF), dry matter after flowering (DMAF) and total dry matter (TDM). Nitrogen fertilization affects the balance of PAR and, consequently, the canola yield.

(C) 2018 SBAgro. All rights reserved.

\section{Introduction}

Cultivation of canola occurs under different environmental conditions, from temperate to subtropical and tropical regions (Zeleke et al., 2011; Rondanini et al., 2012). The surrounding environment is the most important factor in determining the final crop yield in all canola cultivation sites. It is estimated that more than $85 \%$ of grain yield (YLD) of spring canola (Zhang et al., 2013) and about 70\% of YLD of winter canola (MarjanovićJeromela et al., 2011) may be affected by environmental factors although canola shows considerable plasticity in its response to environmental conditions (MarjanovićJeromela et al., 2011; Gan et al., 2016). This facilitates 
field YLD improvement by regulating the requirements of canola by modifying environmental resources, as well as adopting adequate crop management practices (Sidlauskas and Bernotas, 2003). These adjustments are particularly important in southern Brazil, where meteorological variability is high during growing seasons.

Photosynthetically active radiation (PAR) is the most important meteorological/environmental variable used to increase plant biomass (Fagan et al., 2013). It acts directly on photosynthesis and is indirectly related to YLD (Lake and Sadras, 2017). The coefficients of interception efficiency $\left(\varepsilon_{i}\right)$ and absorption efficiency $\left(\varepsilon_{\alpha}\right)$, light extinction coefficient ( $k$ ), and PAR use efficiency (RUE) are the main indicators used to evaluate the interaction of PAR with the plant canopy in agricultural systems (VarletGrancher et al., 1989; Monsi and Saeki, 1953; Fagan et al., 2013; Manevski et al., 2017). The understanding of these relations is fundamental, since the available PAR in the canopy may be affected by crop management practices (Fagan et al., 2013).

The intercepted PAR by the spring canola (Brassica napus L.) depends on the leaf area index (LAI) (Edwards and Hertel, 2011; Nied, 2013; Zhang and Flottmann, 2016), development of reproductive structures (Fochesatto et al., 2016) and by $\mathrm{N}$ topdressing fertilization (Dreccer et al., 2000). The RUE is the coefficient that indicates how the intercepted/absorbed PAR was used by the crop for biomass production. It can vary based on different factors, such as environmental stresses, phenological stage, genotypes (Lake and Sadras, 2017), water and $\mathrm{N}$ availability (Wang et al., 2012), cultivated species, crop management approach, weather conditions (Manevski et al., 2017), and plant density (Morrison and Stewart, 1995), as well as the interaction between these factors (Lake and Sadras, 2017). Therefore, studies on the importance of RUE to canola crop management are of fundamental relevance (Kuai et al., 2016).

Canola responds positively to $\mathrm{N}$ availability in two ways. First, by increasing the nutrient uptake capacity through leaf area (LA) alteration. Second, by improving the use efficiency related to the photosynthetic rate (Lemaire et al., 2008). These situations positively favor biomass production until flowering and YLD (Lack et al., 2011; Ma et al., 2015). For canola, the understanding of how these processes occur is crucial, because, as far as we know, this species has a relatively low $\mathrm{N}$ use efficiency, which does not exceed 60\% (Bouchet et al., 2016). However, increasing rates of $\mathrm{N}$ application have a positive effect on YLD, namely when the environment is favorable to the crop (Ma and Herath, 2016), but also when $\mathrm{N}$ is applied between the stages of rosette leaf formation and the beginning of flowering (Ma et al., 2015), given that $\mathrm{N}$ absorption is greater during canola main stem elongation
(Norton, 2016). Contrastingly, inadequate $\mathrm{N}$ applications can produce deficiencies that compromise nutrient use efficiency (Ma and Herath, 2016), with reduction of LAI, biomass production and consequently YLD (Lemaire et al., 2008). For this reason, the definition of the limits of crop physiological responses to $\mathrm{N}$ is fundamental (Bouchet et al., 2016).

In the main regions of cultivation of the world, canola YLD is highly variable (i.e., from 1,000 to 4,000 $\left(\mathrm{kg} \mathrm{ha}^{-1}\right)$ ); (Rondanini et al., 2012). In Brazil, most YLD records vary between 1,000 and 2,000 $\mathrm{kg} \mathrm{ha}^{-1}$ (Nied, 2013), although with YLD indications probably below that lower limit, depending on the $\mathrm{N}$ amount applied (Kaefer et al., 2014) and the inter-annual meteorological conditions (Wang et al., 2012; Ma and Herath, 2016). However, the YLD potential of this species is actually greater than that currently reached in Brazil, as YLDs of $5,000 \mathrm{~kg} \mathrm{ha}^{-1}$ have been reported in other countries (Gomez and Miralles, 2011; Lilley et al., 2015; Gan et al., 2016). The YLD potential is also established in the vegetative (Zhang and Flottmann, 2016) and in the beginning of the flowering phases (Chongo and McVetty, 2000). In these phases, the YLD potential is associated with greater plant vigor and growth, and higher allocation of biomass to the leaves, which is subsequently translocated for silique and grain formation (Robertson et al., 2004; Arvin et al., 2004; Zhang and Flottmann, 2016), and is also associated with crop growth rate (Zhang and Flottmann, 2016). This aspect has been poorly studied in environments with high climatic variability and is very poorly understood in canola production in southern Brazil.

Considering that many factors related to PAR and $\mathrm{N}$ in canola cultivation are still not well known, the objective of this study was to quantify and evaluate the coefficients of interception, absorption and use of solar radiation and its effects on yield of spring canola influenced by $\mathrm{N}$ topdressing fertilization.

\section{Material and Methods}

Two experiments were carried out in the experimental area of EMBRAPA Wheat $\left(28^{\circ} 11^{\prime} 11^{\prime \prime} S, 52^{\circ} 19^{\prime} 31^{\prime \prime} \mathrm{W}\right.$ at $689 \mathrm{~m}$ ) during 2013 and 2014. According to the Köppen classification, the climate in the region is $\mathrm{Cfa}$ (Alvares et al., 2013). The soil is classified as Rhodic Hapludox. In the summer before canola cultivation, liming was performed for $\mathrm{pH}$ correction, and the areas were also cultivated with soybean (Glycine max L.) in 2013 and with common beans in 2014. In 2013, $2 \mathrm{tha}^{-1}$ of gypsum were applied before sowing of canola to chemically and physically recover the soil.

The experimental design consisted of randomized blocks with four replicates of plots with $127.5 \mathrm{~m}^{2}$ in 2013 and $60 \mathrm{~m}^{2}$ in 2014. The treatments consisted of five 
nitrogen $(\mathrm{N})$ doses applied in topdressing fertilization: $\mathrm{T} 1$ $=10, \mathrm{~T} 2=20, \mathrm{~T} 3=40, \mathrm{~T} 4=80$ and $\mathrm{T} 5=160 \mathrm{~kg} \mathrm{ha}^{-1}$ of $\mathrm{N}$. The combination of urea (50\%) and ammonium sulfate (50\%) was utilized. In the T4 and $\mathrm{T} 5$ treatments, the $\mathrm{N}$ doses were divided respectively in two and three applications, being the first when plants exhibited 4-5 developed leaves and the others every 10 days.

The sowing of canola hybrid Hyola 61 was performed in the $22^{\text {nd }}$ of April 2013, following a conventional cultivation system, and on the $29^{\text {th }}$ of April 2014, under a no-tillage system. We established $0.34 \mathrm{~m}$ between rows and a sowing density of ca. 40 plants per $\mathrm{m}^{2}$. Sowing was manually performed on rows opened by seed drill. The drill also placed fertilizers in the soil before sowing. In the first year, 10,25 and $25 \mathrm{~kg} \mathrm{ha}^{-1}$ of $\mathrm{N}, \mathrm{P}_{2} \mathrm{O}_{5}$ and $\mathrm{K}_{2} \mathrm{O}$ fertilizers were applied, and in the second year, 10,50 and $50 \mathrm{~kg} \mathrm{ha}^{-1}$ of $\mathrm{N}$, $\mathrm{P}_{2} \mathrm{O}_{5}$ and $\mathrm{K}_{2} \mathrm{O}$. Control of weeds, pests and diseases of canola was conducted when required.

During the crop cycle, data on daily incident global solar radiation (SR, in $\left.\mathrm{MJ} \mathrm{m}^{-2} \mathrm{day}^{-1}\right)$, maximum ( $\mathrm{Tx}$, in $\left.{ }^{\circ} \mathrm{C}\right)$, minimum $\left(\mathrm{Tn}\right.$, in $\left.{ }^{\circ} \mathrm{C}\right)$ and mean $\left(\mathrm{T}\right.$, in $\left.{ }^{\circ} \mathrm{C}\right)$ air temperatures, rainfall ( $\mathrm{R}$, in $\mathrm{mm})$, and wind speed (W, in $\mathrm{m} \mathrm{s}^{-1}$ ) were collected at the meteorological station near the experimental area. Relative air humidity ( $\mathrm{RH}$, in \%) data was obtained from the meteorological station belonging to the National Institute of Meteorology (INMET) in Passo Fundo, RS, $10 \mathrm{~km}$ away from the experimental area. The data were grouped by ten-day periods and compared with the historic series from 1980 to 2010 (30 years).

After the sowing, the phenology was evaluated three times per week, according to Iriarte and Valetti (2008). The following stages were identified when $50 \%$ of the plants in the plot exhibited characteristics of that stage on the main stems: emergence (E), rosette leaf formation (R), beginning of flowering (BF), end of flowering (EF), and physiological maturation (M). Two sequential plants were collected per plot every 15 days. The leaves were removed and stored in paper bags in order to determine the leaf dry matter (LDM) to estimate the LAI, based on the relationship between LDM and leaf area (LA) (Deligios et al., 2013). At the vegetative phase, after $\mathrm{R}$ and before BF stages, leaf samples were randomly collected in all treatments in both years and stored in paper bags for the estimation of LDM and linear models of LA for 2013 (equation 1) and 2014 (equation 2):

$$
\begin{aligned}
& L A_{2013}=36.72247+151.8746 * L D M \\
& L A_{2014}=15.41303+155.0487 * L D M
\end{aligned}
$$

With estimated LA at each collection time, LAI was calculated as the ratio of $L A$ and the area of the two collected sequential plants $(S)$, with the equation 3 : where $L A$ and $S$ are given respectively in $\mathrm{m}^{2}$ of leaf and $\mathrm{m}^{2}$ of soil.

The two-week samplings of LAI were fitted into a nonlinear sigmoidal model (Singer et al., 2011; Petter et al., 2016) to describe the evolution of the daily LAI ( $\left.L A I_{d}\right)$ from stage $\mathrm{E}$ to $\mathrm{BF}$, and as a function of the thermal time (TT, in ${ }^{\circ} \mathrm{C}$ day $\left.^{-1}\right)$, with the equation 4 :

$L A I_{d}=a /(1+\exp (-(T T-X o) / b))$

where $a$ is the maximum asymptotic value of the $L A I_{d}$, Xo is the inflection point when $50 \%$ of the expected response occurs, and $b$ is the slope of the variable response. During LA decrease, i.e., after BF and until the end of the crop cycle, a linear model was fitted to obtain the $\mathrm{LAI}_{d}$ with the equation 5:

$L A I_{d}=a+b * T T$

where $a$ is the linear and $b$ the angular coefficients. The TT was calculated by combining Tx, Tn, and lower (Tb) and upper (TB) base temperatures (Ometto, 1981) for canola. The $\mathrm{Tb}$ and $\mathrm{TB}$ used were respectively of $5{ }^{\circ} \mathrm{C}$ and $30^{\circ} \mathrm{C}$ (Dalmago et al., 2009).

Dry matter accumulated until canola flowering (DMF, in $\mathrm{g} \mathrm{m}^{-2}$ ) was determined in the two sequential plants per plot that were collected and stored in paper bags. At the $\mathrm{M}$ stage, the height of three plants $(\mathrm{PH})$ was determined in each plot using a ruler. Subsequently, an area of $1.02 \mathrm{~m}^{2}$ in 2013 and another of $6.0 \mathrm{~m}^{2}$ in 2014 were collected per plot and stored in cotton bags for YLD determination. All packed samples were placed in a drying oven with forced air circulation at approximately $70^{\circ} \mathrm{C}$ until reaching constant weight. Afterwards, the samples were weighed to quantify the total dry matter (TDM, in $\mathrm{g} \mathrm{m}^{-2}$ ). The dry matter after flowering (DMAF, in $\mathrm{g} \mathrm{m}^{-2}$ ) was calculated by the difference between TDM and DMF.

For YLD determination, the samples were placed in a stationary thresher to separate the grains with sieves. Then, grains were packed in paper bags and placed again in the drying oven until reaching constant weight to obtain the grain dry matter (GDM). The GDM was corrected to $8 \%$ moisture for YLD estimation with the equation 6:

$Y L D=G D M / A$

where, GDM is given in $\mathrm{kg}$ and $A$ is the area in hectares.

The crop harvest index ( $\mathrm{HI}$ ) was estimated using DMAF and the GDM (equation 7): 
$H I=(D M A F / G D M) * 100$

For PAR determination, we used sensors built with five parallel amorphous silicon cells (Chartier et al., 1989) and calibrated with a SQ-110 sensor (Apogee Instruments, Logan, UT, USA). The PAR transmitted by the canopy (PARtr) was measured with four sensors (Singer et al., 2011) per treatment, which were leveled at $5 \mathrm{~cm}$ from the ground, transverse to the cultivation row, and fixed to wooden sticks. Three sensors were installed facing the canopy at about $1 \mathrm{~m}$ above the canopy to measure the PAR reflected by the soil-crop set (PARrf). To measure the incident PAR (PARin) in 2013, we used the mean estimation from two sensors installed at $1.5 \mathrm{~m}$ above the canopy. For 2014, the SQ-110 sensor was used. PAR measurements began at 67 days after emergence (DAE) in 2013, and at 47 DAE in 2014.

The sensors were connected to the channel multiplexer AM16/32B (Campbell Scientific, São Paulo, SP, BR), connected to a CR1000 datalogger (Campbell Scientific, São Paulo, SP, BR). Readings were taken every 30 seconds and means were stored every 15 minutes. The PAR data were recorded in $\mu \mathrm{mol} \mathrm{m} \mathrm{m}^{-2} \mathrm{~s}^{-1}$ and transformed to $\mathrm{MJ} \mathrm{\textrm {m } ^ { - 2 }}$ day $^{-1}$, according to equation 8 proposed by Thimijan and Heins (1983):

$\operatorname{PAR}_{\mathrm{MJ}}=\Sigma_{\text {daily }}\left(\mathrm{PAR}_{\mu \mathrm{mol}} * t /(4.596 * 1,000,000)\right)$

where $t$ is the time in seconds between the two consecutive samplings, 4.596 is the conversion factor of $\mu \mathrm{mol}$ to $\mathrm{J}$ and $1,000,000$ is the conversion factor of $\mathrm{J}$ to $\mathrm{MJ}$.

With the PAR data, the intercepted PAR (PARit) and the absorbed PAR (PARab) were calculated respectively with equations 9 and 10:

PARit $=$ PARin - PARtr

PARab $=$ PARin - PARtr - PARrf

The intercept efficiency of PARit by canola $\left(\varepsilon_{i}\right)$ was calculated with the equation 11 :

\section{$\varepsilon_{\mathrm{i}}=$ PARit/PARin}

With the daily values of $\varepsilon_{i}$ and $L A I_{d}$ up to the BF stage (ca. max LAI), the canopy $k$ coefficient was estimated by adjusting the angular coefficient " $b$ " in the linearization of the Monsi and Saeki (1953) equation, which was adapted from the Law of Beer (Fagan et al., 2013) with the equation 12:

$\ln \left(1-\varepsilon_{\mathrm{i}}\right)=-k^{*} L A I_{d}$ where $k$ equals to the modulus of $k$ and $l n$ is the natural logarithm. With $\mathrm{k}$ estimated for each replicate and/or treatment, PARit ${ }_{\text {est }}$ was estimated for the periods in which there was no reading at the beginning of the crop cycle, and on the days that there was no data recording due to system failures. For this, the equation 13 , adapted from the Law of Beer was used:

PARit $_{\text {est }}=$ PARin $e^{-k^{*} \text { LAI }^{d}}$

where $e$ is the basis of the natural logarithm. From the PARit $_{\text {est }}, \varepsilon_{i}$ was calculated for the missing periods and/or days with equation 11 , to compose the data series of the $\varepsilon_{i}$ of the crop cycle.

The data of $\varepsilon_{i}$ were presented as a function of accumulated TT for the main canola developmental stages and as a function of $\mathrm{LAI}^{\mathrm{d}}$. In the second case, the $\varepsilon_{i}$ data after crop establishment ( $\approx 20 \mathrm{DAE}$ ) until the BF stage (ca. max LAI) were fitted to a Rise to Maximum exponential function (Nied, 2013), in which coefficients have biological significance and the $\mathrm{LAI}^{\mathrm{d}}$ is the independent variable, according to the equation 14 :

$\varepsilon_{i}=a\left(1-e^{-b^{*} L A I^{d}}\right)$

where $a$ is the maximum $\varepsilon_{i}, e$ is the basis of the natural logarithm and $b$ is the increasing rate of $\varepsilon_{i}$ by the variation of one unit of the $L^{2}{ }^{d}$. In turn, the absorption efficiency of PAR $\left(\varepsilon_{a}\right)$ was obtained by adjusting the angular coefficient "b" between PARit and PARab.

The RUE of the PARab was calculated as the ratio of TDM and the accumulated PARab between the stages $\mathrm{E}$ and $\mathrm{M}$. The PARab data before the beginning of the measurements and on the days with missing data were estimated with the equation 15:

$\mathrm{PARab}_{\text {est }}=$ PARit $_{\text {est }} * \varepsilon_{a}$

where PARab ${ }_{\text {est }}$ is the estimated PARab. For the days with PAR measurement, the data calculated by equation 10 were used.

The dose of maximum agronomic efficiency (MAE) (Ma et al., 2015) by $\mathrm{N}$ was calculated with equation 16 :

$M A E=-b / 2 a$

where $a$ and $b$ are coefficients of the quadratic equation fitted to the data. Moreover, the maximum value of the Y-axis $\left(\mathrm{Y}_{\mathrm{MAE}}\right)$ was calculated with the equation 17 (Ma et al., 2015):

$Y_{\text {MAE }}=(-b 2 / 4 a)+c$ 
where $a, b$ and $c$ are the coefficients of the quadratic equations adjusted to the data. The R software was used for statistical analyses.

\section{Results and Discussion}

During the two experimental years there were differences in meteorological conditions. The accumulated incident global solar radiation (SR) was similar (approximately $165 \mathrm{MJ} \mathrm{m}^{-2}$ ) to the normal climate of the region (181 $\mathrm{MJ} \mathrm{m}^{-2}$ ). However, finer differences were observed in the 10-day periods, and the SR was lower in 2014 than in 2013, especially during the period of canola growth. There were larger differences between years for $\mathrm{T}$, Tn, and Tx. In 2014, the variations were less dramatic and closer to the climate normal than in 2013. The $\mathrm{T}$ was $14.0^{\circ} \mathrm{C}$ in 2013 and $15.1^{\circ} \mathrm{C}$ in 2014 , with lower values in 2013 concentrated from the end of the vegetative growth until the end of the crop cycle. A similar pattern was observed for Tn and Tx. In 2014, the Tn was greater than the climate normal over nearly the entire crop cycle (Figure 1). Thermal differences were also observed in the number of days wherein $\mathrm{T}$ was lower than $15^{\circ} \mathrm{C}$ (94 days in 2013 but 72 days in 2014). The greatest number of cold days in 2013 was related to the highest frost occurrence, with 11 records during the crop cycle, but only 8 in 2014 (data not shown). Regarding water indicators, rainfall was approximately 35\% (2013) and 45\% (2014) above normal, especially during vegetative growth and flowering in 2013 and during rosette leaf formation and vegetative growth in 2014 (Figure 1).

In the canola cycle, the $\varepsilon_{i}$ of PAR presented a similar response in the two years, with increasing values from the beginning of the cycle until the BF stage, following a sigmoidal trend of biological growth (Singer et al., 2011; Petter et al., 2016). After BF stage, the $\varepsilon_{i}$ remained constant during flowering, but showed a decline during grain filling (Figure 2), especially at the end of that period due to silique maturation. Until rosette leaf formation and during the vegetative growth phase, $\varepsilon_{i}$ was respectively of 4 and $77 \%$ in 2013, with lower means than in 2014 (26 and 77\% for the same phases, respectively). During flowering and at the end of grain filling, $\varepsilon_{i}$ was greater in 2013 (98 and $93 \%$, respectively) than in 2014 ( 87 and $78 \%$, respectively). The difference in $\varepsilon_{i}$ until rosette leaf formation and during the vegetative growth phase between years was observed,

Figure 1. Incident global solar radiation (SR; upper left), mean (T; upper right), minimum (Tn; center left), maximum (Tx; center right) air temperatures, and rainfall (R; lower right and left) in ten-day periods of the canola cycle in 2013 and 2014 in Passo Fundo, RS, Brazil. The particular canola cultivation stages are written above in each panel. Data for years and mean yearly data are highlighted with different symbols, connected by lines.
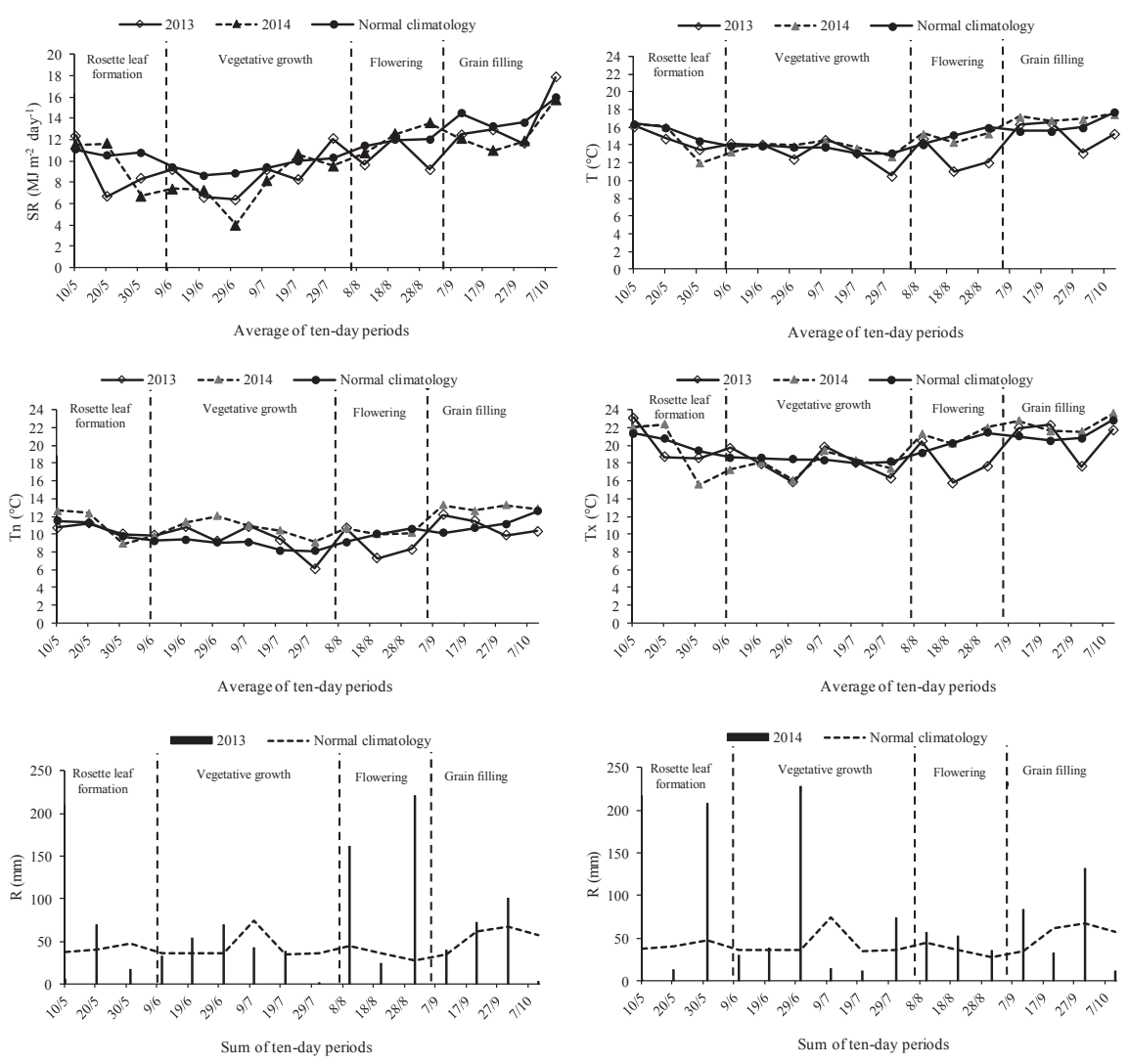
owing to the lower T, Tn, and Tx in 2013 (Figure 1). This probably promoted lower plant growth rates in relation to 2014, in which T was higher (Tian et al., 2017). This may be explained by the greater number of days with $\mathrm{T}$ lower than $15^{\circ} \mathrm{C}$ in 2013 (94 days compared to 72 days in 2014), which may have been favorable for canola acclimation and biomass production at low air temperatures (Rife and Zeinali, 2003). The inversion observed in $\varepsilon_{i}$ during flowering can be partially attributed to the PAR interception by flowers and/or siliques. According to Fochesatto et al. (2016), flowers and siliques are responsible for more than $70 \%$ of PAR interception during flowering.

Among the $\mathrm{N}$ treatments, variability of $\varepsilon_{i}$ was greater in 2014 than in 2013, according to the higher standard error of the $a$ and $b$ coefficients (Table 1). In 2014, $\varepsilon_{i}$ did not responded to $\mathrm{N}$ treatments as expected, given that lower values were estimated for greater $\mathrm{N}$ doses, whereas higher values were estimated for treatments with less $\mathrm{N}$. In both years, the lowest $\varepsilon_{i}$ was observed in the T1 treatment (Figure 2), because of the lower LAI in T1 (Figure 3A-B). Especially in 2013, the lower amount of $\mathrm{N}$ applied in T1 resulted in lower LAI. Meanwhile $\varepsilon_{i}$ did not follow an expected trend for all treatments in 2014, probably due to the inconsistency of LAI estimates based on LDM. This inconsistency can be attributed to failures in PAR measurements in T1 during 2014. Canola responds to the $\mathrm{N}$ increase raising the rate of physiological processes, such as photosynthesis, but also morphological processes, such as LA growth (Lemaire et al., 2008) and maintenance of larger leaf numbers for longer periods (Dreccer et al.
2000). Furthermore, these processes are closely related (Manevski et al., 2017), therefore being responsible for the increase in $\varepsilon_{i}$ of PAR and grain production potential.

The maximum $\varepsilon_{i}$ occurred close to canola flowering (Figure 2), when the maximum LAI was observed (Figure $3 A-B)$, with $\varepsilon_{i}$ close to one in all treatments and years, except for T5 in $2014\left(\varepsilon_{i}=0.87\right)$. In 2013, the maximum $\varepsilon_{i}$ was significantly greater in extreme treatments (T1 and T5), whereas in 2014, the maximum $\varepsilon_{i}$ was greater in T1 and T4 (Table 1). This finding is reinforced by the results presented by Dreccer et al. (2000), who obtained a maximum $\varepsilon_{i}$ of $86 \%$ for same N dose used in T5. However, in 2013, about 90\% of the PAR was intercepted when the LAI was close to 4, as reported by Edwards and Hertel (2011), that is, before the maximum LAI close to flowering (ca. 600 degrees day accumulated) (Figures 2, 3A-B). Nevertheless, the same $\varepsilon_{i}$ value was reached with LAI between 2 and 3 (Nied, 2013; Zhang and Flottmann, 2016), close to flowering in 2014. This indicates that the maximum $\varepsilon_{i}$ were affected by other factors other than LA increase and longer duration, as a function of $\mathrm{N}$ treatments (Dreccer et al., 2000).

The $k$ coefficient was different among treatments and between years, with minimum values of 0.55 and 0.59 and maximum values of 0.78 and 1.09 , respectively for 2013 and 2014 (Table 2). These results are consistent and highly significant $(P<0.001)$, with high $r^{2}$ for the linear regressions derived from Monsi and Saeki (1953) used to obtain $k$ (equation 13), and general standard errors lower than $4 \%$ (Table 2). Treatment T1 presented the lowest $k$ and did not differ between years. For treatment T2, $k$

Table 1. Parameters ( $\mathrm{a}$ and $\mathrm{b}$ ) of the Rise to Maximum exponential function type for the photosynthetically active solar radiation interception efficiency $\left(\varepsilon_{\mathrm{i}}\right)$ of canola as a function of the leaf area index in years 2013 (top) and 2014 (bottom), after topdressing $\mathrm{N}$ fertilization treatments (T1-T5:10, 20, 40, 80 and $160 \mathrm{~kg} \mathrm{ha}^{-1}$ ). Associated standard errors (SE) and minimum and maximum 95\% confidence intervals (CI) are also shown.

\begin{tabular}{|c|c|c|c|c|c|c|c|c|}
\hline \multirow{4}{*}{$\begin{array}{l}\mathbf{N} \text { treatment } \\
\left(\mathbf{k g ~ h a}^{-1}\right)\end{array}$} & \multicolumn{8}{|c|}{ Parameters/Statistics } \\
\hline & \multicolumn{4}{|c|}{ a } & \multicolumn{4}{|c|}{ b } \\
\hline & \multirow[b]{2}{*}{ value $^{1}$} & \multirow[b]{2}{*}{ SE } & \multicolumn{2}{|c|}{$\mathrm{Cl}(95 \%)$} & \multirow[b]{2}{*}{ value } & \multirow[b]{2}{*}{ SE } & \multicolumn{2}{|c|}{$\mathrm{Cl}(95 \%)$} \\
\hline & & & $\min$. & $\max$ & & & $\min$. & $\max$. \\
\hline \multicolumn{9}{|c|}{ Year 2013} \\
\hline 10 & 0.991 & 0.00218 & 0.987 & 0.996 & 0.543 & 0.00348 & 0.536 & 0.550 \\
\hline 20 & 0.981 & 0.00163 & 0.785 & 0.991 & 0.766 & 0.00920 & 0.755 & 0.776 \\
\hline 40 & 0.980 & 0.00125 & 0.977 & 0.982 & 0.791 & 0.00413 & 0.783 & 0.800 \\
\hline 80 & 0.978 & 0.00137 & 0.976 & 0.981 & 0.688 & 0.00405 & 0.680 & 0.696 \\
\hline 160 & 0.995 & 0.00211 & 0.991 & 0.999 & 0.656 & 0.00503 & 0.646 & 0.666 \\
\hline \multicolumn{9}{|c|}{ Year 2014} \\
\hline 10 & 1.123 & 0.03720 & 1.048 & 1.197 & 0.461 & 0.02540 & 0.410 & 0.511 \\
\hline 20 & 0.997 & 0.01090 & 0.976 & 1.019 & 0.924 & 0.02240 & 0.879 & 0.968 \\
\hline 40 & 0.972 & 0.00624 & 0.959 & 0.984 & 0.811 & 0.01310 & 0.785 & 0.837 \\
\hline 80 & 1.042 & 0.01580 & 1.011 & 1.074 & 0.915 & 0.03370 & 0.848 & 0.982 \\
\hline 160 & 0.876 & 0.00714 & 0.861 & 0.890 & 1.111 & 0.02740 & 1.057 & 1.166 \\
\hline
\end{tabular}

${ }^{1}$ Maximum $\varepsilon_{\mathrm{i}}$ estimated by the model. 
Figure 2. Photosynthetically active solar radiation interception efficiency $\left(\varepsilon_{\mathrm{i}}\right)$ as a function of thermal time sum (TT) in ${ }^{\circ} \mathrm{C}$ throughout the canola crop cycle after the topdressing N fertilization treatments T1-T5 $\left(10,20,40,80\right.$ and $160 \mathrm{~kg}^{-1} \mathrm{a}^{-1}$, respectively shown in different lines) for the year 2013 (left) and 2014 (right), in Passo Fundo, RS, Brazil. The particular canola cultivation stages are written above in each panel.
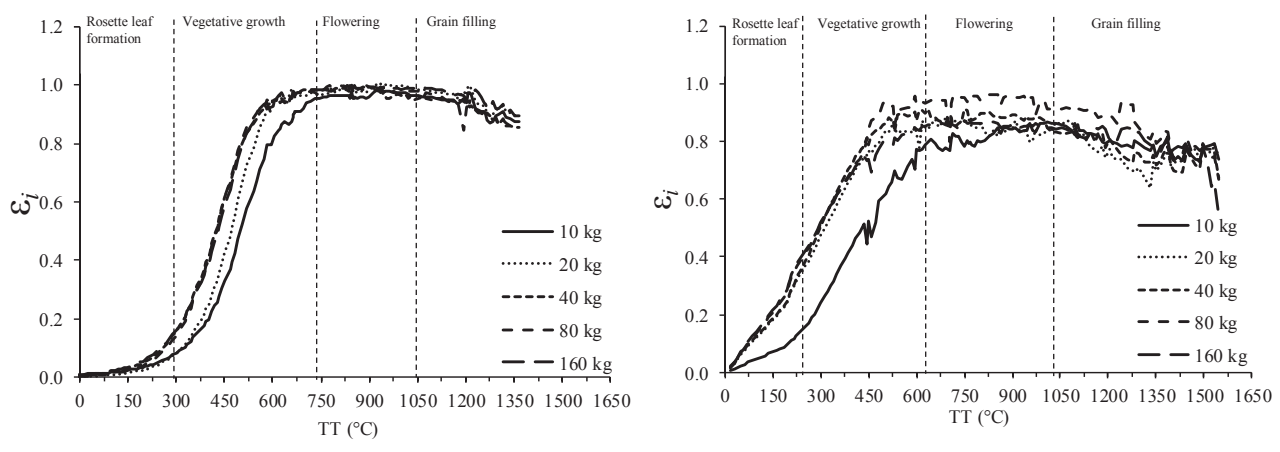

Table 2. Light extinction coefficients (k), standard errors (SE), Student's t-test of the model, 95\% confidence intervals (CI), and coefficient of determination $\left(\mathrm{r}^{2}\right)$ for the interior of canola canopy in years 2013 (top) and 2014 (bottom) after topdressing $\mathrm{N}$ fertilization treatments (on the left) conducted in Passo Fundo, RS, Brazil. Yearly means are shown under each treatment for each year.

\begin{tabular}{lccccc}
$\begin{array}{l}\text { N treatment } \\
\left(\mathbf{k g ~ h a}^{-1}\right)\end{array}$ & $\mathbf{k}$ & SE & $\begin{array}{c}\text { p }<\text { t-test } \\
\text { Year } 2013\end{array}$ & $\mathbf{C l}(95 \%)$ & $\mathbf{r}^{2}$ \\
\hline 10 & 0.55 & 0.01197 & $<0.0001$ & $0.521-0.571$ & 0.99 \\
\hline 20 & 0.76 & 0.02234 & $<0.0001$ & $0.719-0.809$ & 0.97 \\
\hline 40 & 0.78 & 0.03089 & $<0.0001$ & $0.720-0.845$ & 0.94 \\
\hline 80 & 0.64 & 0.01723 & $<0.0001$ & $0.602-0.671$ & 0.96 \\
\hline 160 & 0.71 & 0.02616 & $<0.0001$ & $0.658-0.764$ & 0.95 \\
\hline Yearly mean & 0.70 & 0.01173 & $<0.0001$ & $0.673-0.719$ & 0.95 \\
\hline & & $Y e a r$ & 2014 & & \\
\hline 10 & 0.59 & 0.01869 & $<0.0001$ & $0.549-0.623$ & 0.91 \\
\hline 20 & 1.04 & 0.02045 & $<0.0001$ & $1.003-1.085$ & 0.98 \\
\hline 40 & 0.80 & 0.01937 & $<0.0001$ & $0.757-0.834$ & 0.96 \\
\hline 80 & 1.09 & 0.03554 & $<0.0001$ & $1.025-1.166$ & 0.90 \\
\hline 160 & 1.04 & 0.02316 & $<0.0001$ & $0.992-1.085$ & 0.98 \\
\hline Yearly mean & 0.89 & 0.01547 & $<0.0001$ & $0.863-0.924$ & 0.90 \\
\hline
\end{tabular}

was maintained within the range reported by Dreccer et al. (2000); treatments with lower $\mathrm{N}$ doses exhibited lower $k$ values (Table 2). There was no significant difference between treatments T4 and T5. An inverse response was observed between years, however, with lower $k$ in 2013 and higher $k$ in 2014 compared to T2 and T3.

In this study, differences in maximum $\varepsilon_{i}$ and $k$ may be attributed to random changes in plant architecture between the two years (Arendonk et al., 1997). This hypothesis is supported by the distinct heights of canola plants observed at the end of the crop cycle (Figure 3C), which were on average lower in 2014 than in 2013. Therefore, the canopy may have been more compact in 2014, probably concentrating most LAI in the plant's upper layer. Contrastingly, in 2013 the LAI was better distributed, allowing greater light penetration in the canopy (Figure 3A-B). According to Arendonk, et al. (1997), the change in plant architecture is related to changes in morphology and leaf positioning traits, which are affected by air temperature. The higher T (Figure 1) and the lower number of days with air temperature favoring acclimation induced the development of smaller and thinner leaves, producing smaller plants (Stefanowska et al., 1999; Slauenwhite and Qaderi, 2013) in 2014 than in 2013. This may have enabled the development of a more planophile leaf arrangement (Arendonk, et al., 1997), and thus lower PAR transmission to the interior of the canopy, affecting the maximum $\varepsilon_{i}$ and $\mathrm{k}$ coefficient in 2014. In addition to differences in plant architecture and changes in leaf morphology between the years, differences in PAR reflected by canola were also observed (Figure 3D). In 2014, the PAR reflected was greater than in 2013, which corroborates with the plant architecture change. Therefore, this supports the hypothesis that greater reflection means less PAR 
Figure 3. Leaf area index (LAI) as a function of thermal time sum (TT) in ${ }^{\circ} \mathrm{C}$ for 2013 (A) and 2014 (B). Mean plant height (PH) in the end of the 2013 and 2014 cycles (C). Confidence intervals are shown for each year. Mean PAR reflected as a function of thermal time sum (TT) in ${ }^{\circ} \mathrm{C}$ for the canola canopy cultivated in the 2013 (empty circles) and 2014 (black triangles) agricultural years treated with topdressing $\mathrm{N}$ fertilization $\left(10 \mathrm{~kg} \mathrm{ha}^{-1}, 20 \mathrm{~kg} \mathrm{ha}^{-1}, 40 \mathrm{~kg} \mathrm{ha}^{-1}, 80 \mathrm{~kg} \mathrm{ha}^{-1}\right.$ and $\left.160 \mathrm{~kg} \mathrm{ha}^{-1}\right)$.
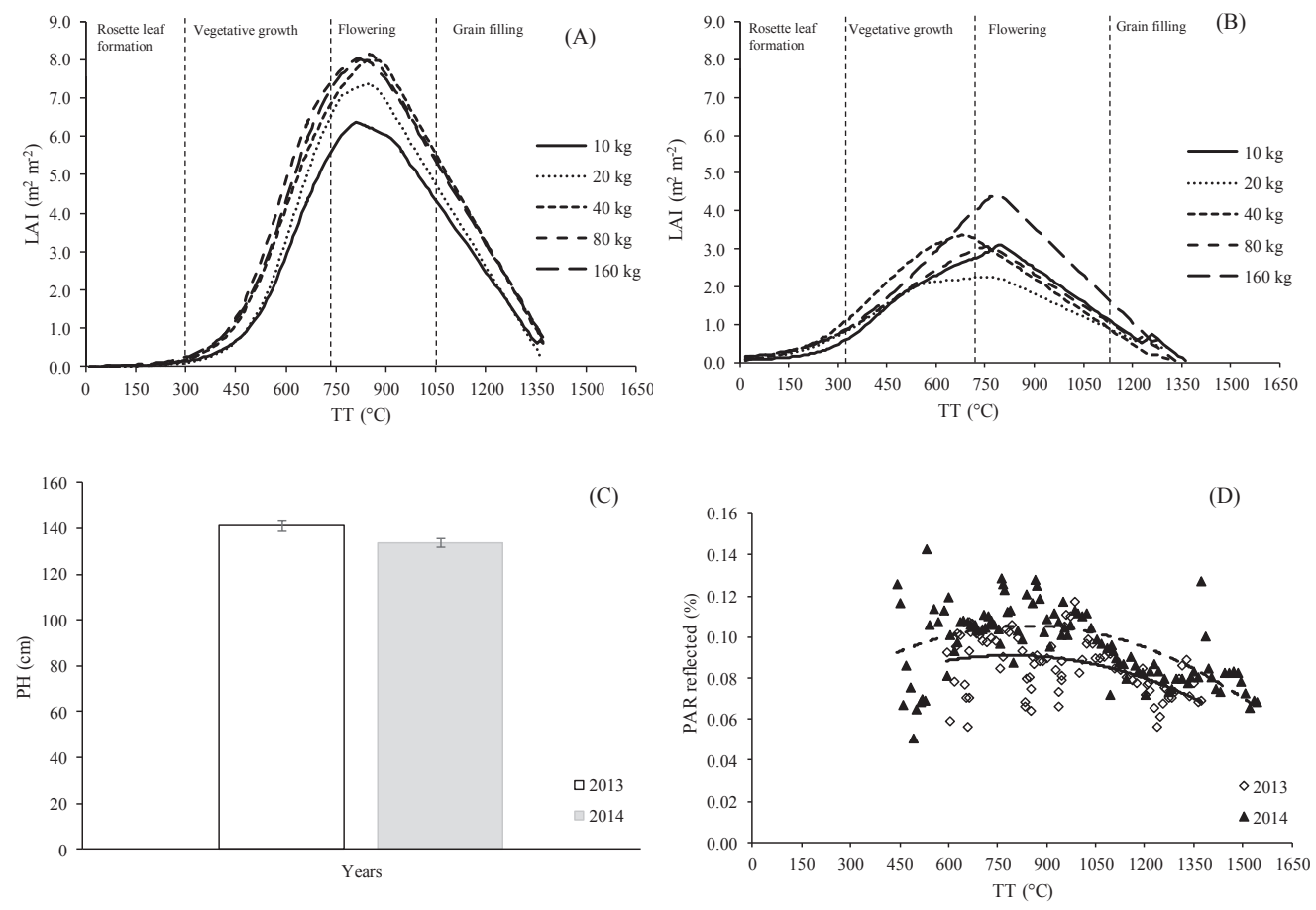

penetration in the canopy, and lower PAR interception $\left(\varepsilon_{i}\right.$ maximum) and $k$.

The $\varepsilon_{a}$ was close between treatments and years, ranging from 0.86 to 0.93 (Figure 4A, C). In each year, there were differences between the $\mathrm{N}$ treatments. The greatest $\varepsilon_{a}$ was found for T3 during 2013, but for T1, T2 and T3 during 2014 (Figure 4B, D). The mean $\varepsilon_{a}$ of canola (between 86 and 93\% of PARit) was slightly below the 95\% limit recommended for most agricultural crops (Varlet-Grancher et al, 1989). However, $\varepsilon_{a}$ mean is still within the range suggested by Yates and Steven (1987) and Nied (2013) for the crop: 88 to $91 \%$. The differences in the geometric and optical properties of the canopy (Varlet-Grancher et al, 1989) influenced by the $\mathrm{N}$ treatments and the inter-annual variability of the meteorological conditions (Figure 1) may also explain $\varepsilon_{a}$. These canopy properties are represented by mean differences in plant height and PAR reflection (ca. 9\% in 2013 and 11\% in 2014) (Figure 3C-D).

Regarding RUE, a significant response was observed for the $\mathrm{N}$ doses $(P<0.05)$ with quadratic polynomial in the two years. There was a better fit in 2014 compared to 2013, as indicated by higher $r^{2}$ scores (Figure 5A). In 2013, RUE had greater variation between treatments from ca. 2.6 (treatment T1) until ca. $3.7 \mathrm{~g} \mathrm{~m}^{-2} \mathrm{MJ}^{-1}$ (treatment T5). In 2014, maximum RUE was $1.2 \mathrm{~g} \mathrm{~m}^{-2} \mathrm{MJ}^{-1}$ (Figure 5A). There was a significant difference for RUE between years, according to the confidence intervals of the coefficients

of the equations. However, the maximum CI for the $b$ coefficient in 2014 was not different from the minimum CI of $b$ coefficient in 2013 (Table 3). The result of equations 16 and 17 produced a MAE of respectively 89.0 and $110.0 \mathrm{~kg} \mathrm{ha}^{-1}$ of $\mathrm{N}$ for 2013 and 2014.

The RUE values observed in 2013 were generally within the range of 1.69 to $3.88 \mathrm{~g} \mathrm{MJ}^{-1}$, previously reported for spring canola (Morrison and Stewart, 1995). A significant variation was observed regarding the $\mathrm{N}$ doses, and it was in average ca. $270 \%$ greater than that of 2014, which is in accord to results from Dreccer et al. (2000). The RUE of all treatments in 2014 remained below the values observed by Nied (2013) who conducted his study at the same location as that of the present study, but used only one $\mathrm{N}$ dose of $70 \mathrm{~kg} \mathrm{ha}^{-1}$ in topdressing fertilization. The lower $k$ values in 2013 compared to 2014 (Table 2), associated with the increasing $\varepsilon_{a}$ between doses of $\mathrm{N}$ in 2013, but decreasing in 2014 (Figure 4B, D), explain part of the variations. This is because variations in $k$ and $\varepsilon_{a}$ occurred due to changes in plant architecture affecting the RUE (Caviglia and Sadras, 2001). Further, the RUE differences between years may be attributed to different meteorological conditions (Figure 1), given that $\mathrm{N}$ treatments were the same for both years, and that the experimental areas were located nearby, with identical soil type and basic fertilization (Manevski et al., 2017). This alternative explanation was also suggested by Wang et al. (2012) and Manevski et al. (2017) after 
Figure 4. Relationship between the photosynthetically active solar radiation intercepted (PARint) and absorbed (PARab) on canola crops grown in 2013 (A) and 2014 (C) after the application of topdressing N fertilization (T1-T5: 10, 20, 40, 80 and 160 kg ha-1). Confidence intervals (CI) of the angular coefficient (absorption efficiency) of the linear equations for the $\mathrm{N}$ treatments in years 2013 (B) and 2014 (D).
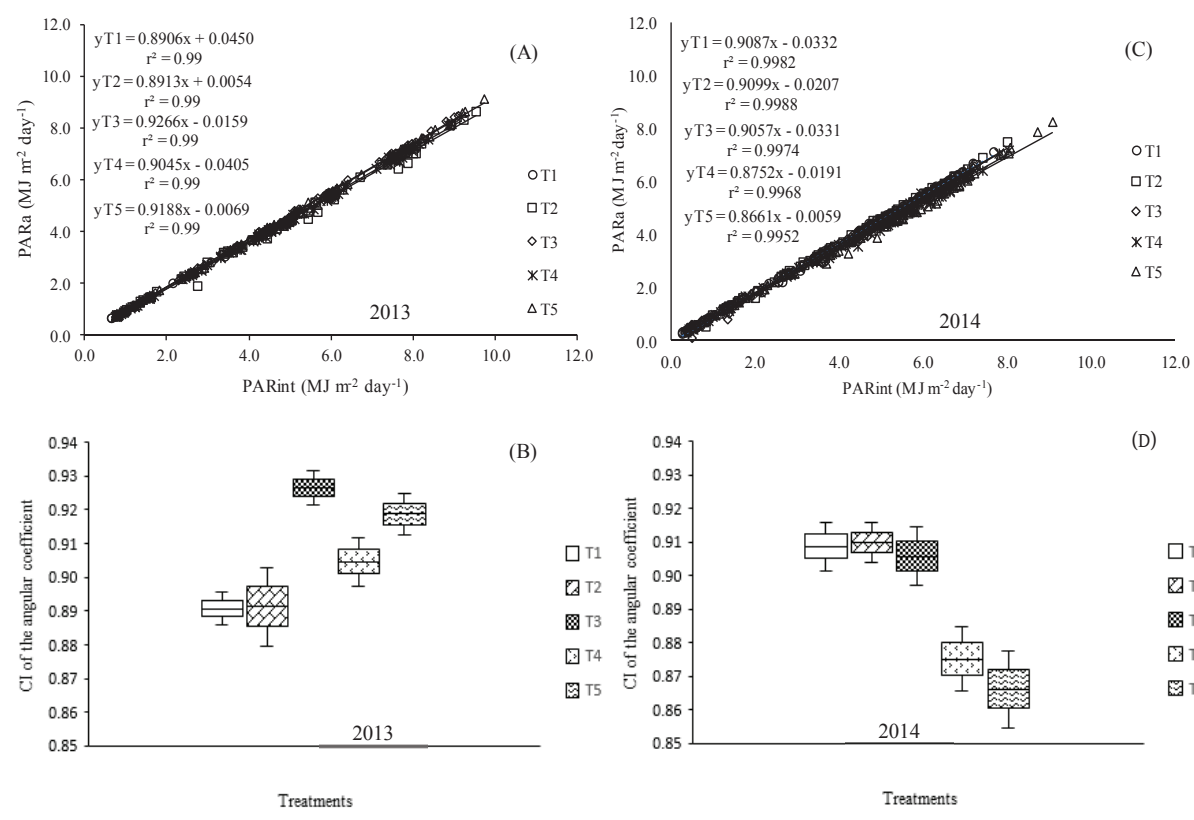

(D)

Table 3. Standard error (SE), and minimum and maximum confidence intervals (CI) for the linear polynomial equation coefficients (a, b) and for the quadratic equation coefficients $(\mathrm{a}, \mathrm{b}, \mathrm{c})$ of variables ${ }^{1}$ related to canola vegetative growth and yield after topdressing $\mathrm{N}$ fertilization (10, 20, 40, 80 and $\left.160 \mathrm{~kg} \mathrm{ha}^{-1}\right)$ in years 2013 and 2014 in Passo Fundo, RS, Brazil. Empty spaces (-) indicate that there was no adjusted equation and/or the estimated coefficient was not significant.

\begin{tabular}{|c|c|c|c|c|c|c|c|}
\hline \multirow{3}{*}{ Variable $^{1}$} & \multirow{3}{*}{$\begin{array}{l}\text { Statistical } \\
\text { Indicator }\end{array}$} & \multicolumn{6}{|c|}{ Confidence interval of the polynomial equation coefficients } \\
\hline & & \multicolumn{3}{|c|}{2013} & \multicolumn{3}{|c|}{2014} \\
\hline & & a & b & c & a & b & c \\
\hline \multirow{3}{*}{$\operatorname{RUE}\left(\mathrm{g} \mathrm{m}^{-2} \mathrm{MJ}^{-1}\right)$} & SE & 0.233 & 0.008 & $<0.001$ & 0.015 & 0.001 & $<0.001$ \\
\hline & $\mathrm{Cl} \min$ & 1.786 & 0.008 & $<-0.001$ & 0.885 & 0.005 & $<-0.001$ \\
\hline & $\mathrm{Cl} \max$ & 2.907 & 0.047 & $<-0.001$ & 0.956 & 0.008 & $<-0.001$ \\
\hline \multirow{3}{*}{ TDM $\left(\mathrm{g} \mathrm{m}^{-2}\right)$} & SE & 77.904 & 2.711 & 0.015 & 5.344 & 0.186 & 0.001 \\
\hline & $\mathrm{Cl} \min$ & 759.851 & 5.791 & -0.103 & 327.439 & 4.510 & -0.028 \\
\hline & $\mathrm{Cl} \max$ & 1134.445 & 18.828 & -0.030 & 353.134 & 5.404 & -0.023 \\
\hline \multirow{3}{*}{ DMF $\left(\mathrm{g} \mathrm{m}^{-2}\right)$} & SE & 11.603 & 0.141 & - & 13.668 & 0.166 & - \\
\hline & $\mathrm{Cl} \min$ & 543.619 & 1.153 & - & 179.466 & 0.289 & - \\
\hline & $\mathrm{Cl} \max$ & 599.409 & 1.823 & - & 245.185 & 1.084 & - \\
\hline \multirow{3}{*}{$\operatorname{DMAF}\left(\mathrm{g} \mathrm{m}^{-2}\right)$} & SE & 85.216 & 2.966 & 0.017 & 18.312 & 0.637 & 0.004 \\
\hline & $\mathrm{Cl} \min$ & 190.402 & 2.814 & -0.102 & 99.786 & 2.033 & -0.030 \\
\hline & $\mathrm{Cl} \max$ & 600.156 & 17.074 & -0.021 & 187.837 & 5.097 & -0.012 \\
\hline \multirow{3}{*}{ YLD $\left(\mathrm{kg} \mathrm{ha}^{-1}\right)$} & SE & 250.937 & 8.733 & 0.049 & 20.990 & 0.731 & 0.004 \\
\hline & $\mathrm{Cl} \min$ & 1793.238 & 11.657 & -0.295 & 1011.274 & 8.388 & -0.058 \\
\hline & $\mathrm{Cl} \max$ & 2999.844 & 53.648 & -0.058 & 1112.201 & 11.900 & -0.038 \\
\hline \multirow{3}{*}{ HI } & SE & - & - & - & 0.010 & $<0.001$ & $<0.001$ \\
\hline & $\mathrm{Cl} \min$ & - & - & - & 0.305 & -0.002 & $<0.001$ \\
\hline & $\mathrm{Cl} \max$ & - & - & - & 0.352 & $<-0.001$ & $<0.001$ \\
\hline
\end{tabular}

${ }^{1} \mathrm{RUE}=$ photosynthetically active solar radiation use efficiency; TDM = total dry matter at the canola harvest; DMF = dry matter accumulated until flowering; DMAF = dry matter after flowering; YLD = grain yield; $\mathrm{HI}$ = crop harvest index. 
the RUE assessment in different perennial and annual species that exhibit different carbon metabolic routes $\left(C_{3}\right.$ and $C_{4}$ species). Furthermore, Kuai et al. (2016) observed a significant effect of the inter-annual meteorological variability on the RUE in winter canola. The mean Tn found in our study indicate that the environmental conditions were more favorable to canola development in the vegetative phase, similar to results from Riffkin et al. (2012), who found that prevailing the formation of large leaves with greater biomass production potencial. This contrast, however with the results of Stefanowska et al., (1999) and Slauenwhite and Qaderi (2013), who found that the high air temperature favors the formation of smaller leaves and with lower biomass production potential.

There was a significant difference between years (Table 3 ) and $N$ treatments ( $P<0.05$; Figure 5$)$ for DMF. There was a better fit for DMF to $\mathrm{N}$ doses in 2013 (higher $r^{2}$ ) than in 2014. In the first year there was an increment of $1.5 \mathrm{~g} \mathrm{~m}^{-2}$ of DMF for each $\mathrm{kg}$ of $\mathrm{N}$ in contrast to the second year, with an increment of ca. $0.7 \mathrm{~g} \mathrm{~m}^{-2}$, resulting respectively in 810 (2013) and $322 \mathrm{~g} \mathrm{~m}^{-2}$ (2014). Thus, in the MAE for $\mathrm{N}$ use, the DMF in 2013 was more than double that of 2014. A different response was verified with DMAF, which presented a quadratic fit to the $\mathrm{N}$ for both years (Figure 5), with significant differences between years, as verified by the confidence interval of the angular coefficients. The data fit to the quadratic function was better for 2014, with higher $r^{2}$ and lower standard errors (Table 3).

Increased biomass production in function of increasing $\mathrm{N}$ doses up to a certain level is an expected response for canola (Bouchet et al., 2016). In 2013 and 2014, the difference in produced TDM was significant among the $\mathrm{N}$ doses, but with a high variability between years. The values was close to the TDM observed by Cheema et al. (2012). Kaefer et al. (2014) noted TDM ranging from 1,260 to $1,350 \mathrm{~g} \mathrm{~m}^{-2}$ for an estimated population of 45 plants per $\mathrm{m}^{-2}$. In 2013, TDM was close to the values found by other authors in the same region (Kaefer et al., 2014), whereas TDM in 2014 was less than half of the value estimated for 2013. This result also reinforces the indication that canola $\mathrm{N}$ response is strongly related to meteorological and environmental conditions during the in cultivation period (Riffkin et al., 2012), suggesting the strategy of improving the N dose of MAE. The doses of MAE for TDM were close to the doses used by Cheema et al. (2010), who observed higher TDM with $90 \mathrm{~kg} \mathrm{ha}^{-1}$ of $\mathrm{N}$, but differ from the MAE observed by Kaefer et al. (2014), who noted $74 \mathrm{~kg} \mathrm{ha}^{-1}$ and 73 $\mathrm{kg} \mathrm{ha}^{-1}$ in two years. Therefore, for the southernmost areas of Brazil, canola can have a high potential of production due to $\mathrm{N}$ topdressing fertilization application in cold years, as found in the 2013 experimental year. Moreover, canola can be more responsive to $\mathrm{N}$ topdressing fertilization in

Figure 5. Effect of topdressing $\mathrm{N}$ fertilization on photosynthetically active solar radiation use efficiency (RUE), total dry matter at harvest (TDM), dry matter accumulated until flowering (DMF), dry matter after flowering (DMAF), grain yield (YLD) and crop harvest index (HI) in the 2013 (black dots) and 2014 (empty dots) agricultural years in Passo Fundo, RS, Brazil. Each data point refers to one of the five $\mathrm{N}$ treatments (T1-T5: 10, 20, 40,80 and $160 \mathrm{~kg} \mathrm{ha}^{-1}$ ). Correlation coefficients are shown for each year accordingly.
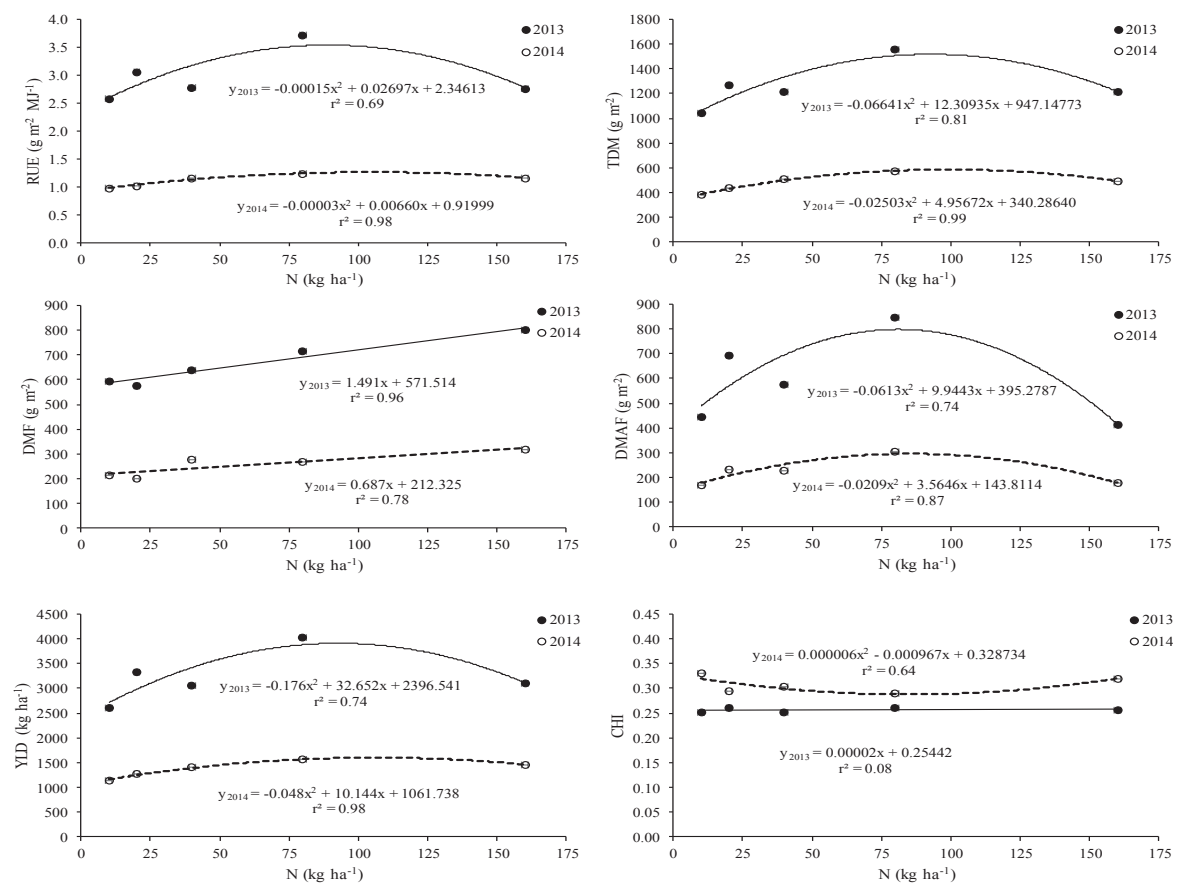
Figure 5. Canola grain yield (YLD) as a function of the photosynthetically active radiation use efficiency (RUE; upper left), dry matter accumulated until flowering (DMF), dry matter after flowering (DMAF) and total dry matter at harvest (TDM) after topdressing $N$ fertilization treatments (T1:T5: 10, 20, 40, 80 and $160 \mathrm{~kg} \mathrm{ha}^{-1}$ ) in the 2013 (black dots) and 2014 (empty dots) agricultural years in Passo Fundo, RS, Brazil.
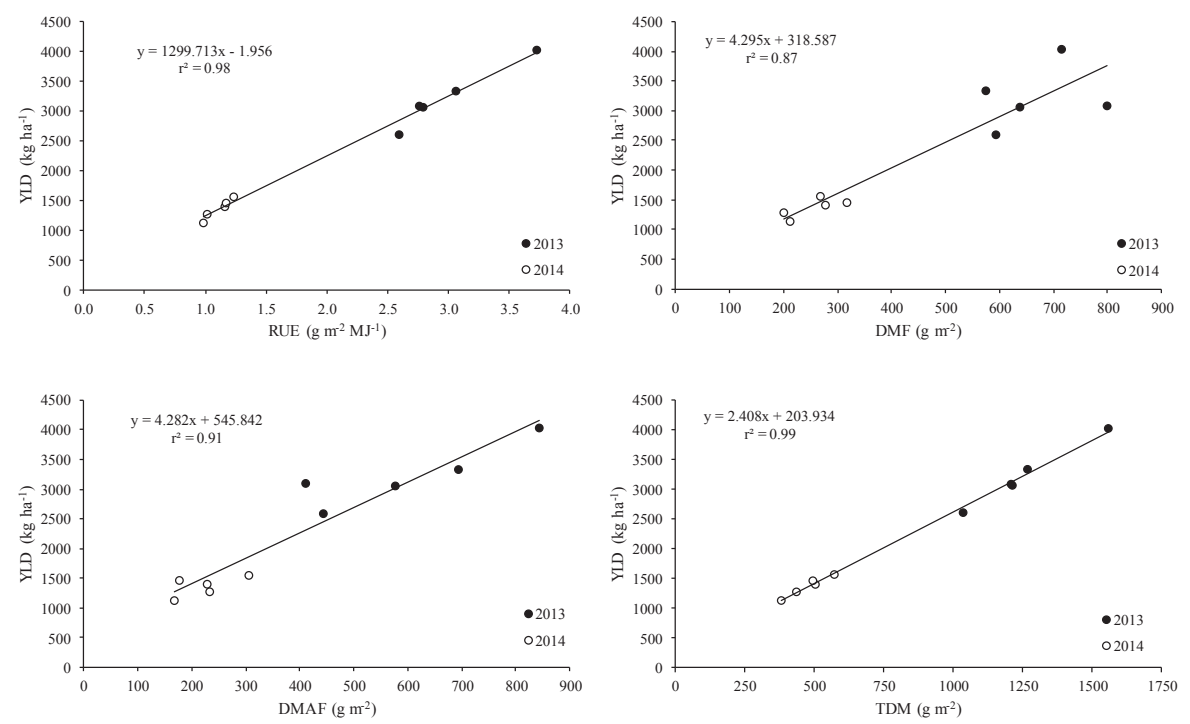

environments with lower Tn, higher altitude, and previous plant cold acclimation.

Despite the existence of distinct environmental potentials, for the crop, however, it is essential to combine them into one integrative biological potential. For canola, the YLD potential is associated with the biomass production during the vegetative phase, until the beginning of the grain filling stage (Chongo and McVetty, 2000, Zhang and Flottmann, 2016). In this sense, we found different $\mathrm{N}$ dose responses in the two years, with a linear fit until flowering (DMF) and a quadratic fit after flowering (DMAF) between biomass and $\mathrm{N}$ doses (Figure 5). These indicate distinct $\mathrm{N}$ use strategies during the crop cycle. The linear fit until flowering corroborates the hypothesis that canola YLD is associated with DMF production (Lack et al., 2011; Ma et al., 2015) and with the environmental conditions of the vegetative phase. Therefore, management strategies that increase DMF may favor canola YLD, since plants would reach flowering with greater YLD potential (Figure 5). However, the integrated evaluation of the results (years and $\mathrm{N}$ doses) also shows a high relationship between YLD and DMAF. This is explained by the rapid leaf senescence in the beginning of flowering (Dreecer et al., 2000; Nied, 2013). In this process, photoassimilated reserves are rapidly translocated to guarantee the production of the first flowers, while the remaining flowers will only be formed by the photoassimilate production during silique formation and grain filling (Dreecer et al., 2000). Thus, if the accumulation of DMF is responsible for canola productive potential (Chongo and McVetty, 2000; Zhang and Flottmann, 2016), the formation of YLD is associated with DMAF produced after flowering, as demonstrated by the symmetrical response of DMAF and YLD to $\mathrm{N}$ doses in our experiments (Figure 5).

The TDM and YLD showed significant differences between years and $N$ treatments (Table 3), with a significant response for both traits and years $(P<0.05$; Figure 5$)$. The values were greater for 2013 for both TDM and YLD, but the fit was stronger for $2014\left(r^{2}>0.90\right)$. The TDM ranged from ca. 1,000 to $1,600 \mathrm{~g} \mathrm{~m}^{-2}$ in 2013. In 2014, the maximum TDM did not reach $600 \mathrm{~g} \mathrm{~m}^{-2}$, which corresponds to less than half of the TDM found in 2013. The $\mathrm{N}$ dose for the MAE of TDM was $92.7 \mathrm{~kg} \mathrm{ha}^{-1}$ in 2013, but $99.0 \mathrm{~kg} \mathrm{ha}^{-1}$ in 2014, resulting respectively in 1,518 and $586 \mathrm{~g} \mathrm{~m}^{-2}$ for 2013 and 2014. Hence, TDM production was 2.6 times higher in 2013 than in 2014 at the N dose of MAE. Considering the DMF produced in treatment T5 (MAE dose) and TDM in the MAE dose (Figure 5), more than 50\% of TDM (53\% in 2013 and $55 \%$ in 2014) was produced until flowering, and the remaining of the TDM was added after flowering.

YLD variation was the same as observed for TDM, reaching $4,000 \mathrm{~kg} \mathrm{ha}^{-1}$ in T4 and above $2,500 \mathrm{~kg} \mathrm{ha}^{-1}$ in T1 (Figure 5) for 2013. Meanwhile, YLD varied from $1,130 \mathrm{~kg} \mathrm{ha}^{-1}$ in T1 to $1,553 \mathrm{~kg} \mathrm{ha}^{-1}$ in T4 for 2014. Similarly, Kaefer et al. (2014) reported a YLD ranging from $628 \mathrm{~kg} \mathrm{ha}^{-1}$ (with $\mathrm{N}$ dose of $0 \mathrm{~kg} \mathrm{ha}^{-1}$ ) to $1,815 \mathrm{~kg} \mathrm{ha}^{-1}$ (with $100 \mathrm{~kg} \mathrm{ha}^{-1}$ of N). In another study, Nied (2013) obtained an YLD of 1,000$2,000 \mathrm{~kg} \mathrm{ha}^{-1}$ with ca. $70 \mathrm{~kg} \mathrm{ha}^{-1}$ of N. The N dose of MAE found here was respectively of 92.8 and $105.7 \mathrm{~kg} \mathrm{ha}^{-1}$ for YLD in 2013 and 2014, corresponding to a reference value of $100 \mathrm{~kg} \mathrm{ha}^{-1}$ of $\mathrm{N}$. These doses are greater than the value of $89 \mathrm{~kg} \mathrm{ha}^{-1}$ of $\mathrm{N}$ reported by Kaefer et al. (2014). Over 
both years and treatments, YLD was highly dependent on RUE and TDM, with $r^{2}$ greater than 0.95. YLD was also highly related to DMF and DMAF, with $r^{2}$ respectively of 0.87 and 0.91 (Figure 5). There was an increase of 2.4 and $1,300 \mathrm{~kg} \mathrm{ha}^{-1}$ of grains respectively for RUE and TDM for each gram unit of TDM per $\mathrm{m}^{2}$ produced. This holds true also for each gram unit of TDM per $\mathrm{m}^{2} \mathrm{MJ}^{-1}$ accumulated. Moreover, there was an increase of 4.30 and $4.28 \mathrm{~kg} \mathrm{ha}^{-1}$ of grains for each gram unit per $\mathrm{m}^{-2}$ for DMF (until flowering) and accumulated DMAF (after flowering).

Regarding HI, there was practically no difference for $\mathrm{N}$ in 2013, in contrast to the results of Dreccer et al. (2000). However, there was a significant quadratic response for $\mathrm{HI}$ in 2014. The HI overall means were 0.26 and 0.31 for the consecutive years. These values are in accord with normal values for canola, which vary from 0.20 to 0.40 (Fan et al., 2017).

The YLD and HI are two classic indicators for evaluating the agronomic performance of grain crops. In this study, however, HI was not a good indicator of canola performance, as in other crops as wheat (Triticum aestivum L.), maize (Zea mays L.), oat (Avena sativa L.), barley (Hordeum vulgare L.), lentil (Lens culinaris L.), soybean (Glycine max L.), sorghum (Sorghum bicolor L. Moench) (Fan et al., 2017; Thapa et al., 2017). We found a quadratic response in 2014, but there is no biological explanation for the concave shape of the function. This observation was probably due to an unknown bias (Figure 5 and Table 3). According to Zhang and Flottmann (2016), the high yield performance of canola in favorable environments is determined by the storage/translocation relationship during different plant developmental phases. This suggests that although YLD variability was high, YLD values are within the range expected for canola. Most of the canola cultivation regions worldwide show YLD means ranging from 1,000 to 4,000 $\mathrm{kg} \mathrm{ha}^{-1}$ (Rondanini et al., 2012). Therefore, YLD should be a better indicator to evaluate the canola productive performance than the HI. Moreover, variations in canola YLD were also reported by Kirkegaard et al. (2016), and they mentioned that YLD reduction for a given sowing date could be attributed to lower biomass production in the same sowing date because of the higher Tn. Thus, it seems clear that high $\mathrm{N}$ availability during the canola cycle, associated with mild air temperature conditions can contribute to increasing the YLD crop potential.

\section{Conclusions}

The interception, absorption, and use efficiency of photosynthetically active solar radiation increase with increase in nitrogen application via topdressing fertilization.

The increase in the coefficients of interception and use of photosynthetically active solar radiation associated with nitrogen fertilization result in increase of dry matter accumulated until and during flowering, but also at the grain filling stage, and further the total dry matter and grain yield of canola.

The response of use efficiency of the photosynthetically active solar radiation, dry matter after flowering, total dry matter, and grain yield to the nitrogen applied in topdressing fertilization is quadratic, with a maximum agronomic efficiency dose of $100 \mathrm{~kg} \mathrm{ha}^{-1}$ of nitrogen.

The response to the nitrogen doses of dry matter accumulated until canola flowering is linear and positive.

The yield of canola grains varies linearly and positively as a function of solar radiation use efficiency, dry matter accumulated until flowering, dry matter after flowering, and total dry matter of canola.

\section{Funding}

This work was supported by the National Center of Wheat Research (EMBRAPA) [grants numbers 03.15.00.038.00.00 and 03.15.00.039.00.00]; and the National Council for Scientific and Technological Development (CNPq) [grant numbers 306274/2013-2, 304284/2013-0, 310487/2012-9 and 304055/2014-0].

\section{References}

ALVARES, C. A.; STAPE, J. L.; SENTELHAS, P. C.; GONÇALVES, J. L. M.; SPAROVEK, G. Köppen's climate classification map for Brazil. Meteorologische Zeitschrift, v. 22, n.6, p. 711-728, 2013.

ARENDONK, J. J. C. M. V.; NIEMANN, G. J.; BOON, J. J.; LAMBERS, H. Effects of nitrogen supply on the anatomy and chemical composition of leaves of four grass species belonging to the genus Poa, as determined by image-processing analysis and pyrolysis-mass spectrometry. Plant, Cell and Environment, v. 20, p. 881-887, 1997.

ARVIN, P.; AZIZI, M.; FIRUZEH, R. Study of dry matter partitioning into leaf, stem and pod at different oilseed rape cultivars. International Journal of Biosciences, v. 4, n. 10, p. 243-248, 2014.

BOUCHET, A. S.; LAPERCHE, A.; BISSUEL-BELAYGUE, C.; SNOWDON, R.; NESI, N.; STAHL, A. Nitrogen use efficiency in rapeseed. A review. Agronomy for Sustainable Development, v.36, p. 1-20, 2016.

CAVIGLIA, O. P.; SADRAS, V. O. Effect of nitrogen supply on crop conductance, water and radiation use efficiency of wheat. Field Crops Research, v. 69, p. 259-266, 2001.

CHARTIER, M.; BONCHRETIEN, P.; ALLIRAND, J.M.; GOSSE, G. Utilization des cellules au silicium amorphe pour la mesure du rayonnement photosynthíquement actif (400-700 nm). Agronomie, Paris, v. 9, p. 281$284,1989$.

CHEEMA, M. A.; SALEEM, M. F.; MUHAMMAD, N.; WAHID, M. A.; BABER, B. H. Impact of rate and timing of nitrogen application on yield and quality of canola (Brassica napus L.). Pakistan Journal of Botany, v. 42, p. 1723-1731, 2010.

CHEEMA, M. A.; SATTAR, A.; WAHID, M. A.; SALEEM, M. F.; SADIQ, $S$. Growth, yield and quality response of various canola cultivars under agro-ecological condition of Faisalabad. Pakistan Journal of Agricultural Sciences, v. 49, n.1, p.35-39, 2012.

CHONGO, G.; MCVETTY, P. B. E. Relationship of physiological characters to yield parameters in oilseed rape (Brassica napus L.). Canadian Journal Plant Science, v. 86, p. 1-6, 2000. 
DALMAGO, G. A.; CUNHA, G. R. DA, TOMM, G. O.; SANTI, A.; PIRES, J. L. F. Canola. In: MONTEIRO, J. E. B. A. (Org.). Agrometeorologia dos cultivos: o fator meteorológico na produção agrícola Brasília, DF: INMET. p. 131149, 2009.

DELIGIOS, P. A.; FARCI, R.; SULAS, L.; HOOGENBOON, G.; LEDDA, L. Predicting growth and yield or winter rapeseed in a Mediterranean environment: Model adaptation at a field scale. Field Crops Research, v. 144 , p. 100-112, 2013.

DRECCER, M. F.; SCHAPENDONK, A. H. C. M.; SLAFER, G. A.; RABBINGE, R.; 2000. Comparative response of wheat and oilseed rape to nitrogen supply: absorption and utilization efficiency of radiation and nitrogen during the reproductive stages determining yield. Plant and Soil, v. 220, p. 89-205. 2000.

EDWARDS, J.; HERTEL, K. Canola growth and development. Available at: <http://www.dpi.nsw. gov.au/aboutus/resources/ bookshop/canola-growth-and-development>. Accessed on: 30/03/2013. 2011.

FAGAN, E. B.; MIQUELANTI, N. P.; BONFIM, T. S.; PEREIRA, I. S.; CORRÊA, L. T.; SOARES, J. N. Lei de Beer e sua relação com a ecofisiologia de plantas. Revista do Centro Universitário de Patos de Minas, v. 4, p. 78-97, 2013.

FAN, J.; MCCONKEY, B.; JANZEN, H.; SMITH, L. T.; WANG, H. Harvest index-yield relationship for estimating crop residue in cold continental climates. Field Crops Research, v. 204, p. 153-157, 2017.

FOCHESATTO, E.; NIED, A. H.; BERGAMASCHI, H.; DALMAGO, G. A.; PINTO, D. G.; KOVALESKI, S.; CUNHA, G. R. DA, GOUVÊA, G. A. Interception of solar radiation by the productive structures of spring canola hybrids. Ciência Rural, v. 46, n.10, p. 1790-1796, 2016.

GAN, Y.; HARKER, K. N.; KUTCHER, H. R.; GULDEN, R. H.; IRVINE, B.; MAY, W. E.; O'DONOVAN, J. T. Canola seed yield and phenological responses to plant density. Canadian Journal Plant Science, v. 96, p. 151-159, 2016.

GOMEZ, N. V.; MIRALLES, D. J. Factors that modify early and late reproductive phases in oilseed rape (Brassica napus L.): Its impact on seed yield and oil content. Industrial Crops and Products, v. 34, p. 12771285, 2011.

IRIARTE, L. B.; VALETTI, O. E. Cultivo de colza. Buenos Aires: Instituto Nacional de Tecnologia Agropecuária - INTA. 2008. 156 p.

KAEFER, J. E.; GUIMARÃES, V. F.; RICHART, A.; TOMM, G. O.; MÜLLER, A. L. Produtividade de grãos e componentes de produção da canola de acordo com fontes e doses de nitrogênio. Pesquisa Agropecuária Brasileira, v. 49, n. 4, p. 273-280, 2014.

KIRKEGAARD, J. A.; LILLEY, J. M.; BRILL, R. D.; SPRAGUE, S. J.; FETTELL, N. A.; PENGILLEY, G. C. Re-evaluating sowing time of spring canola (Brassica napus L.) in south-eastern Australia - how early is too early? Crop \& Pasture Science, v. 67, p. 381-396, 2016.

KUAI, J.; SUN, Y.; ZHOU, M.; ZHANG, P.; ZOU, Q.; WU, J.; ZHOU, G. The effect of nitrogen application and planting density on the radiation use efficiency and the stem lignin metabolism in rapeseed (Brassica napus L.). Field Crops Research, v. 199, p. 89-98, 2016.

LACK, S.; POUR, N. E.; MOJADAM, M.; HEIDARNEJAD, M.; 2011. As evaluation of the effects of different nitrogem levels and densities on grain andd oil yields of canola cv. Hayola 401. Avances in Environmental Biology, v. 5, n. 10, p. 3110-3116, 2011.

LAKE, L.; SADRAS, V. Associations between yield, intercepted radiation and radiation-use efficiency in chickpea. Crop \& Pasture Science, v. 68, p. 140-147, 2017.

LEMAIRE, G.; OOSTEROM, E. V.; JEUFFROY, M.; GASTAL, F.; MASSIGNAM, A. Crop species present different qualitative types of response to $\mathrm{N}$ deficiency during their vegetative growth. Field Crops Research, v. 105, p. 253-265, 2008.

LILLEY, J. M.; BELL, L. W.; KIRKEGAARD, J. A. Optimising grain yield and grazing potential of crops across Australia's high-raingall zone: a simulation analysis. Crop \& Pasture Science, v. 66, p. 349-364, 2015.
MA, B. L.; BISWAS, D. K.; HERATH, A. W.; WHALEN, J. K.; RUAN, S. Q.; CALDWELL, C.; EARL, H.; VANASSE, A.; SCOTT, P.; SMITH, D. L. Growth, yield, and yield components of canola as affected by nitrogen, sulfur, and boron application. Journal of Plant Nutrition and Soil Science, v. 178 , n. 4, p. 658-671, 2015.

MA, B. L.; HERATH, A. W. Timing and rates of nitrogen fertilizer application on seed yield, quality and nitrogen-use efficiency of canola. Crop \& Pasture Science, v. 67, p. 167-180, 2016.

MANEVSKI, K.; LAERKE, P. E.; JIAO, X.; SANTHOME, S.; JøRGENSE, U. Biomass productivity and radiation utilization of innovative cropping systems for biorefinery. Agricultural and Forest Meteorology, v. 233, p. 250-264, 2017.

MARJANOVIĆ-JEROMELA, A.; NAGL, N.; GVOZDANOVIĆ-VARGA, J.; HRISTOV, N.; KONDIĆ-ŠPIKA, A.; VASIĆ, M.; MARINKOVIĆ, R. Genotype by environment interaction for seed yield per plant in rapeseed using AMMI model. Pesquisa Agropecuária Brasileira, v. 46, n, 2, p. 174-181, 2011.

MONSI, M.; SAEKI, T. The light factor in plant communities and its significance for dry matter producton. Japanese Journal of Botany, Tokyo, v. 14, p. 22-52, 1953.

MORRISON, M. J.; STEWART, D. W. Radiation use efficiency in summer rape. Agronomy Journal, v. 87, p. 1139-1142, 1995.

NIED, A. H. Parâmetros bioclimáticos e resposta da canola ao ambiente físico. 135f. Tese (Doutorado Fitotecnia/agrometeorologia) - Programa de Pós-Graduação em Fitotecnia, Faculdade de Agronomia, Universidade Federal do Rio Grande do Sul, Porto Alegre, RS. 2013.

NORTON, R. M. Nitrogen management to optimise canola production in Australia. Crop \& Pasture Science, v. 67, p. 419-438, 2016.

OMETTO, A. C. Bioclimatologia vegetal. São Paulo: Ed. Agronômica Ceres. $1981.440 \mathrm{p}$.

PETTER, F. A.; SILVA, J. A. DA, ZUFFO, A. M.; ANDRADE, F. R.; PACHECO, L. P.; ALMEIDA, F. A. Elevada densidade de semeadura aumenta a produtividade da soja? Resposta da radiação fotossinteticamente ativa. Bragantia, v. 75, n. 2, p. 173-183, 2016.

RIFE, C. L.; ZEINALI, H. Cold tolerance in oilseed rape over varying acclimation durations. Crop Science, v. 43, p. 96-100, 2003.

RIFFKIN, P.; POTTER, T.; KEARNEY, G. Yield performance of latematuring winter canola (Brassica napus L.) types in the High Rainfall Zone of southern Australia. Crop \& Pasture Science, v. 63, p. 17-32, 2012.

ROBERTSON, M. J.; HOLLAND, J. F.; BAMBACH, R. Response of canola and indian mustard to sowing data in the grain belt of north-eastern Australia. Australian Journal of Experimental Agriculture, v. 44, p. 43-52, 2004.

RONDANINI, D. P.; GOMEZ, N. V.; AGOSTI, M. B.; MIRALLES, D. J. Global trends of rapessed grain yield stability and rapessed-to-wheat yield ration in the last four decades. European Journal of Agronomy, v. 37, p. 56-65, 2012.

SIDLAUSKAS, G.; BERNOTAS, S. Some factors affecting seed yield of spring oilseed rape (Brassica napus L.). Agronomy Research, v. 1, n. 2, p. 229-243, 2003.

SINGER, J. W.; MEEK, D. W.; SAUER, T. J.; PRUEGER, J. H.; HATFIELD, J. L. Variability of light interception and radiation use efficiency in maize and soybean. Field Crops Research, v. 121, p. 147-152, 2011.

SLAUENWHITE, K. L. I.; QADERI, M. M. Single and interactive effects of temperature and light quality on four canola cultivars. Journal of Agronomy and Crop Science, v. 199, p. 286-298, 2013.

STEFANOWSKA, M.; KURA'S, M.; KUBACKA-ZEBALSKA, M.; KACPERSKA, A. Low temperature affects pattern of leaf growth and structure of cell walls in winter oilseed rape (Brassica napus L.; var. oleifera L.). Annals of Botany, v. 84, p. 313-319, 1999.

THAPA, S.; STEWART, B. A.; XUE, Q.; CHEN, Y. Manipulating plant geometry to improve microclimate, grain yield, and harvest index in grain sorghum. PLoS ONE, v. 12, n.3, p. 1-14, 2017. 
THIMIJAN, R. W.; HEINS, R. D. Photometric, radiometric, and quantum light units of measure: a review of procedures for interconversion. HortScience, Alexandria, v. 18, n.6, p. 818-822, 1983.

TIAN, T.; WU, L.; HENKE, M.; ALI, B.; ZHOU, W.; SORLIN, G. B. Modeling allometric relationships in leaves of young rapessed (Brassica napus, L) grown at different temperature treatments. Frontiers in Plant Science, v. 8 , p. 1-12, 2017.

VARLET-GRANCHER, C.; GOSSE, G.; CHARTIER, M.; SINOQUET, H.; BONHOMME, R.; ALLIRAND, J. M. Mise au point: rayonnement solaire absorbé ou intercepté par un couvert végétal. Agronomie, v. 9, p. 419439, 1989.

WANG, S.; WANG, E.; WANG, F.; TANG, L. Phenological development and grain yield of canola as affected by sowing data and climate variation in the Yangtze River Basin of China. Crop \& Pasture Science, v. 63, p. 478-488, 2012.
YATES, D. J.; STEVEN, M. D. Reflexion and absorption of solar radiation by flowering canopies of oil-seed rape (Brassica napus L.). The Journal of Agricultural Science, v. 109, p. 495-502, 1987.

ZELEKE, K. T.; LUCKETT, D., COWLEY, R. Calibration and testing of the FAO AquaCrop model for canola. Agronomy Journal, v. 103, n. 6, p. 160-1618, 2011.

ZHANG, H.; BERGER, J. D.; MILROY, S. P. Genotype x environment interaction studies highlight the role of phenology in specific adaptation of canola (Brassica napus) to contrasting Mediterranean climates. Field Crops Research, v. 144, p. 77-88, 2013.

ZHANG, H.; FLOTTMANN, S. Seed yield of canola (Brassica napus L.) is determined primarily by biomass in a high-yielding environment. Crop \& Pasture Science, v. 67, p. 396-380, 2016. 


\title{
Uso da radiação solar na melhoria do rendimento de grãos de canola (Brassica napus L., Brassicaceae), influenciada pela adubação nitrogenada em cobertura
}

\author{
Genei Antonio Dalmago ${ }^{\left.1{ }^{*}\right)}$, Daniele Gutterres Pinto $^{2}$, Denise Cybis Fontana ${ }^{2}$, Jorge Alberto de Gouvêa ${ }^{1}$, Homero Bergamaschi $^{2}$, \\ Elizandro Fochesatto ${ }^{3}$ e Anderson Santi ${ }^{1}$ \\ ${ }^{1}$ Embrapa Trigo, Rodovia BR 285, km 294, Caixa Postal 3081, CEP 99050-970 Passo Fundo, RS. E-mail: genei.dalmago@embrapa.br, \\ jorge.gouvea@ embrapa.br e anderson.santi@embrapa.br \\ ${ }^{2}$ Universidade Federal do Rio Grande do Sul - Faculdade de Agronomia. Avenida Bento Gonçalves, 7712, Caixa Postal 15096, CEP 91501.970. Porto Alegre, \\ RS. E-mails: daniele.gutterres@gmail.com, dfontana@ufrgs.br e homerobe@ufrgs.br \\ ${ }^{3}$ Faculdades Integradas do Vale do Iguaçu-Uniguaçu. Rua Padre Saporiti, 717, Bairro Rio D’Areia, CEP 84600-904 União da Vitória, PR. \\ E-mail: elizandrofochesato@hotmail.com \\ ${ }^{(*)}$ Autor para correspondência.
}

INFORMAÇÕES

História do artigo:

Recebido em 15 de junho de 2018

Aceito em 20 de dezembro de 2018

Termos para indexação:

Brassica napus

matéria seca

índice de área foliar

radiação fotossinteticamente ativa

coeficiente de extinção de luz
RESUMO

O objetivo do trabalho foi quantificar e avaliar os coeficientes de interceptação, absorção e uso da radiação solar fotossinteticamente ativa (PAR), e seus efeitos no rendimento de grãos (YLD) da canola de primavera, influenciados pela adubação com nitrogênio (N) em cobertura. Dois experimentos foram realizados em 2013 e 2014 , em blocos casualizados, com quatro repetições e cinco tratamentos de N: T1T5 (10, 20, 40, 80 e $160 \mathrm{~kg} \mathrm{ha}^{-1}$, respectivamente). Variáveis de plantas, balanço de PAR e variáveis meteorológicas foram medidas. A menor eficiência de interceptação da PAR $\left(\varepsilon_{\mathrm{i}}\right)$ ocorreu em T1. O coeficiente de extinção de luz $(\mathrm{k})$ variou de 0,55 a 1,09. A eficiência de absorção de PAR $\left(\varepsilon_{\mathrm{a}}\right)$ variou de 86 a $93 \%$, enquanto a eficiência de uso de PAR (RUE), foi entre 1,2 e 3,7 $\mathrm{g} \mathrm{m}^{-2} \mathrm{MJ}^{-1}$. A dose média de $\mathrm{N}$ para máxima eficiência agronômica (MAE) para o YLD foi de 99,3 $\mathrm{kg} \mathrm{ha}^{-1}$. O YLD variou de acordo com os tratamentos $\mathrm{N}$ e foi influenciado por RUE, matéria seca acumulada até o florescimento (DMF), a matéria seca após a floração (DMAF), e a matéria seca total (TDM). O nitrogênio afeta positivamente os coeficientes do balanço da PAR e por consequência, o rendimento de grãos da canola. 